\title{
Pengaruh Penambahan Tepung Kunyit (Curcuma longa) dalam Ransum Terhadap Performa Produksi Ayam Kampung Super
}

\section{The Effects of Turmeric Flour (Curcuma longa) as Natural Feed Additive on The Performance of Super Native Chicken}

\author{
Harmoko ${ }^{1}$, Wati $\mathrm{NE}^{1}$, Suhadi $\mathrm{M}^{1}$ \\ ${ }^{1}$ Fakultas Peternakan, Universitas Tulang Bawang Lampung. Jl. Gajah Mada No.34 Kotabaru, Bandar \\ Lampung \\ Hharmoko800@gmail.com
}

\begin{abstract}
The aim of the study was to know the effect of Curcuma longa as herbal feed additive on feed consumption, daily body weight gain and feed conversion ratio of super native chicken. The research was conducted at Kemukus Village, Ketapang District, South Lampung Regency. The experimental used 80 unisex of super native chicken 5 weeks old. They were feed a ration with control ration $+0 \%$ turmeric flour (P0), control ration $+0,04 \%$ turmeric flour $(\mathrm{P} 1)$, control ration $+0,08 \%$ turmeric flour $(\mathrm{P} 2)$ and control ration $+0,12 \%$ turmeric flour (P3) during 30 days. The control ration containing $21 \%$ crude protein and $3150 \mathrm{kcal} / \mathrm{kg}$ metabolism energy. The study used a quantitative metodh with completely randomized design with 4 treatments and 4 replications. The results showed that the addition of turmeric flour (Curcuma longa) up to $0,12 \%$ was affected $(P<0,05)$ on feed consumption but did not effect $(P>0,05)$ on daily body weight gain and feed conversion ratio.
\end{abstract}

Keywords: daily body weight gain, feed consumption, feed conversion ratio, super native chicken, turmeric

\section{PENDAHULUAN}

Peningkatan jumlah penduduk sangat berpengaruh terhadap peningkatan pangan nasional khususnya sumber protein hewani. Salah satu protein hewani yang banyak dikonsumsi oleh masyarakat Indonesia adalah daging ayam kampung. Daging ayam kampung sebagai salah satu pensuplai protein hewani. Berdasarkan data dari Direktorat Jenderal Peternakan dan Kesehatan Hewan Kementerian Pertanian RI tahun 2018, konsumsi daging ayam kampung mengalami peningkatan pada setiap tahunnya. Pada tahun 2016 konsumsi daging ayam kampung sebesar 0,626 kg/kapita/tahun. Mengalami peningkatan konsumsi daging ayam kampung pada tahun 2017 sebesar 0,782 kg/kapita/tahun.

Meningkatnya konsumsi daging ayam kampung perlu adanya peningkatan produktivitas ayam kampung. Salah satu peningkatan produktivitas dengan perbaikan kualitas pakan yaitu dengan penambahan feed aditif alami yaitu kunyit (Curcuma longa). Kunyit mengandung kurkumin 3-5\% dan atsiri 2,5-6\% (Hartati, 2013).

Kurkumin berfungsi meningkatkan organ pencernaan ayam kampung super dengan merangsang dinding kantong empedu untuk mengeluarkan cairan empedu dan merangsang keluarnya getah pankreas yang mengandung enzim amilase, lipase dan protease yang berguna untuk meningkatkan pencernaan bahan pakan seperti karbohidrat, lemak dan protein. Minyak atsiri dalam kunyit juga dapat mempercepat pengosongan isi lambung (Adi, 2009). Penambahan tepung kunyit diharapkan dapat meningkatkan konsumsi pakan ayam kampung super yang berpengaruh dalam pembetukan daging serta dapat menghasilkan pertambahan bobot badan ayam kampung super yang optimal. Hal ini mendorong adanya penelitian tentang pengaruh penambahan tepung kunyit (Curcuma longa) dalam pakan ayam kampung super terhadap konsumsi pakan, pertambahan bobot badan dan konversi pakan. 


\section{MATERI DAN METODE}

\section{Materi Penelitian}

Alat yang digunakan dalam penelitian ini adalah kandang, timbangan dengan ketelitian $1 \mathrm{~g}$, wadah pakan, wadah air minum, ember kecil, lembar pengamatan, kamera dan alat tulis. Bahan yang digunakan dalam penelitian ini meliputi 80 ekor ayam kampung super berumur 5 minggu, yang diberi perlakuan selama 30 hari. Ayam ditempatkan dalam 4 petak kandang sesuai dengan jumlah perlakuan. Setiap petak kandang perlakuan dibagi menjadi 4 bagian sebagai ulangan. Setiap ulangan terdapat 5 ekor ayam kampung super.

Perlakuan yang diberikan adalah :

$\mathrm{PO}=$ pakan kontrol $+0 \%$ tepung kunyit

$\mathrm{P} 1=$ pakan kontrol $+0,04 \%$ tepung kunyit

P2 = pakan kontrol $+0,08 \%$ tepung kunyit

$\mathrm{P} 3=$ pakan kontrol $+0,12 \%$ tepung kunyit

Pakan kontrol yang digunakan adalah konsentrat jadi merk Bongsor AB-02 yang diproduksi oleh PT. Agro Sari Nusantara. Kandungan nutrisi pakan kontrol tersaji pada Tabel 1.

Tabel 1. Komposisi ransum dan kandungan nutrien ransum kontrol

\begin{tabular}{lc}
\hline \multicolumn{1}{c}{ Nutrisi } & Jumlah \\
\hline Energi metabolisme (kkal/kg) & $3000-3150$ \\
Protein kasar (\%) & 21 \\
Serat kasar (\%) & 4,0 \\
Lemak (\%) & 7 \\
Kalsium/Ca (\%) & $0,8-1,1$ \\
Fosfor (\%) & 0,5 \\
Abu (\%) & 7,0 \\
Kadar air (\%) & 13 \\
\hline
\end{tabular}

Sumber : PT. Agro Sari Nusantara (2019)

\section{Metode Penelitian}

Ayam kampung super berumur 5 minggu dipelihara selama 35 hari. Ayam kampung super diberi perlakuan pada umur 5 minggu sampai dengan umur 9 minggu dengan perlakuan $\mathrm{P} 0=$ tanpa penambahan tepung kunyit, $\mathrm{P} 1=$ pakan kontrol $+0,04 \%$ tepung kunyit $(0,04 \mathrm{~g} / \mathrm{kg}$ pakan), $\mathrm{P} 2=$ pakan kontrol $+0,08 \%$ tepung kunyit $(0,08 \mathrm{~g} / \mathrm{kg}$ pakan $)$ dan $\mathrm{P} 3=$ pakan kontrol $+0,12 \%$ tepung kunyit $(0,12 \mathrm{~g} / \mathrm{kg}$ pakan). Pemberian pakan, dilakukan 2 kali dalam satu hari pada pagi hari pukul 07.30 WIB dan sore hari pada pukul 15.00 WIB, penimbangan sisa pakan yang dilakukan setiap pagi hari, penimbangan bobot badan ayam dilakukan pada awal dan akhir penelitian.

\section{Analisis Data}

Model linear ulangan seluruh nilai pengamatan dengan rancangan acak lengkap adalah sebagai berikut :

$Y i j=\mu+\mathrm{Tj}+\varepsilon i \mathrm{j}$ 
Keterangan :

$Y_{i j}=$ Hasil pengamatan konsumsi pakan, pertambahan bobot badan dan konversi pakan ke i (P0, P1, P2, P3) dengan ulangan ke - j $(1,2,3,4)$.

$\mathrm{i}=$ Perlakuan penambahan tepung kunyit.

j = Ulangan ke 1, 2, 3 dan 4.

$\mu=$ Rataan ulangan/nilai tengah.

$\mathrm{Tj}=$ Pengaruh perlakuan penambahan tepung kunyit.

$\varepsilon i j=$ Pengaruh galat percobaan dengan perlakuan penambahan tepung kunyit $\quad$ (P0, P1, P2 dan P3) dengan ulangan $\mathrm{ke}-\mathrm{j}(1,2,3,4)$.

Hipotesis statistik yang diuji adalah :

$\mathrm{H}_{0}=\mathrm{T}_{1}=\mathrm{T}_{2}=\mathrm{T}_{3}=0$, tidak terdapat pengaruh penambahan tepung kunyit pada ransum terhadap konsumsi pakan, pertambahan bobot badan dan konversi pakan ayam kampung super.

$\mathrm{H}_{1}=$ Minimal ada satu $\mathrm{T}_{1} \neq 0$, terdapat pengaruh penambahan tepung kunyit pada ransum terhadap konsumsi pakan, pertambahan bobot badan dan konversi pakan ayam kampung super.

Data hasil penelitian diuji $\mathrm{F}$ berdasarkan prosedur sidik ragam dan dilanjutkan dengan uji jarak berganda Duncan (UJGD) pada tarap 5\% dibantu dengan perangkat lunak SPSS version 17.00 untuk mengetahui pengaruh penambahan tepung kunyit terhadap konsumsi pakan, pertambahan bobot badan dan konversi pakan. Kriteria mengambil keputusan adalah apabila nilai probabilitas $P<0,05$, maka ada pengaruh penambahan tepung kunyit terhadap konsumsi pakan, pertambahan bobot badan dan konversi pakan dan sebaliknya apabila nilai probabilitas $\mathrm{P}>0,05$, maka tidak ada pengaruh penambahan tepung kunyit terhadap konsumsi pakan, pertambahan bobot badan dan konversi pakan.

\section{HASIL DAN PEMBAHASAN}

\section{Pengaruh Perlakuan Terhadap Konsumsi Pakan}

Hasil penelitian menunjukkan bahwa penambahan tepung kunyit (Curcuma longa) pada pakan ayam kampung super berpengaruh nyata $(P<0,05)$. Besarnya konsumsi pakan ayam yang mendapat perlakuan P0, P1, P2 dan P3 tersaji pada Tabel 2.

Tabel 2. Konsumsi Pakan Ayam Kampung Super

\begin{tabular}{lcc}
\hline \hline Perlakuan & Rataan g/ekor/hari & Standar Deviasi \\
\hline P0 & $71,40^{\mathrm{b}}$ & 0,56 \\
P1 & $70,93^{\mathrm{b}}$ & 0,66 \\
P2 & $71,23^{\mathrm{b}}$ & 0,34 \\
P3 & $73,31^{\mathrm{a}}$ & 1,61 \\
\hline
\end{tabular}

Keterangan: Superskrip yang berbeda pada kolom yang sama menunjukan pengaruh yang nyata pada taraf $5 \%(P<0,05)$.

Rataan konsumsi pakan ayam kampung super yang diberi perlakuan penambahan tepung kunyit paling tinggi pada P3 yaitu sebesar 73,31 g. Sedangkan besarnya konsumsi ayam P0, P1, dan P2 tidak berbeda nyata yaitu berturut-turut sebesar 71,40 g, 70,93 g, dan $71,23 \mathrm{~g}$. Hasil ini menunjukan bahwa penambahan tepung kunyit pada dosis 0,12\% dapat meningkatkan konsumsi pakan pada ayam kampung super, sedangkan pada dosis yang lain tidak memberikan pengaruh. Kandungan kurkumin dan atsiri pada kunyit mampu meningkatkan nafsu makan pada ayam. Sesuai dengan pendapat Purwanti et al (2010) bahwa tepung kunyit banyak memiliki khasiat salah satunya untuk menambah nafsu makan, sehingga konsumsi pakan meningkat. Hasil penelitian Adha et al (2016) menunjukkan penambahan tepung kunyit dalam pakan ayam sentul betina putih dengan dosis 0,3\% belum memberikan pengaruh yang nyata pada konsumsi pakan. Sedangkan hasil penelitian 
Handayani et al (2017) menunjukkan bahwa penambahan kunyit pada pakan itik hibrida dengan dosis $0,04 \%$ dapat meningkatkan konsumsi pakan dan pertambahan bobot badan. Besarnya konsumsi pakan ayam kampung super yang dipelihara sesuai dengan yang standar, konsumsi pakan ayam kampung umur 6,7,8 dan 9 minggu yaitu sebesar $66 \mathrm{~g}, 729 \mathrm{~g}$, $74 \mathrm{~g}$ dan $80 \mathrm{~g}$ (Yusriani, 2013).

\section{Pengaruh Perlakuan Terhadap Pertambahan Bobot Badan Harian}

Hasil penelitian menunjukkan bahwa penambahan tepung kunyit (Curcuma longa) pada pakan ayam kampung super tidak berpengaruh nyata $(P>0,05)$ terhadap pertambahan bobot badan. Besarnya pertambahan bobot badan ayam yang mendapat perlakuan P0, P1, P2 dan P3 tersaji pada Tabel 3.

Tabel 3. PBBH Ayam Kampung Super dengan Penambahan Tepung Kunyit

\begin{tabular}{lcc}
\hline \hline Perlakuan & Rataan g/ekor/hari & Standar Deviasi \\
\hline P0 & 16,63 & 1,91 \\
P1 & 13,36 & 2,35 \\
P2 & 15,64 & 1,52 \\
P3 & 16,99 & 1,02 \\
\hline \multicolumn{2}{l}{ Keterangan: Superskrip yang berbeda pada kolom yang sama menunjukan pengaruh yang nyata pada } \\
&
\end{tabular}

Besarnya rataan pertambahan bobot badan ayam P0, P1, P2 dan P3 tidak berbeda nyata yaitu berturut-turut sebesar 16,63 g, 13,36 g, 15,64 g dan 16,99 g. Hasil ini menunjukkan bahwa penambahan tepung kunyit pada dosis $0,12 \%$ tidak dapat meningkatkan bobot badan harian pada ayam kampung super. Hal ini sejalan dengan hasil penelitian Widiawati et al (2018) bahwa penggunaan tepung kunyit dalam pakan dengan dosis 0,05\% belum memberikan pengaruh yang nyata terhadap pertambahan bobot badan ayam broiler. Pertambahan bobot badan yang sama pada ayam diduga diakibatkan oleh suhu lingkungan yang tinggi yang mengakibatkan ayam mengalami heat stress. Olanrewaju et al (2006) berpendapat bahwa cekaman panas menghambat suplai nutrien ke jaringan tubuh sehingga berpengaruh terhadap penurunan efisiensi dalam menyerap nutrien untuk produksi dalam meningkatkan bobot badan ayam. Hasil penelitaan Furlan et al (2004) bahwa kenaikan suhu tubuh akan mengakibatkan pengeluaran energi untuk mengurangi beban panas tubuh sehingga menggagu kecernaan, penyerapan dan metabolisme nutrien untuk pertambahan bobot ayam. Pertambahan bobot badan harian ayam kampung super yang dipelihara lebih tinggi daripada standar PBBH ayam kampung pada umur 6,7,8 dan 9 minggu yaitu sebesar $500 \mathrm{~g}, 600 \mathrm{~g}, 700 \mathrm{~g}$ dan $800 \mathrm{~g}$ (Aryanti et al., 2013).

\section{Pengaruh Perlakuan Terhadap Konversi Pakan}

Hasil penelitian menunjukkan bahwa penambahan tepung kunyit (Curcuma longa) pada pakan ayam kampung super tidak pengaruh nyata $(P>0,05)$ terhadap konversi pakan. Besarnya konversi pakan ayam yang mendapat perlakuan P0, P1, P2 dan P3 tersaji pada Tabel 4.

Tabel 4. Konversi Pakan Ayam Kampung Super dengan Penambahan Tepung Kunyit

\begin{tabular}{lcc}
\hline Perlakuan & Rataan $\mathbf{g} /$ ekor/hari & Standar Deviasi \\
\hline P0 & 4,33 & 0,47 \\
P1 & 5,43 & 0,93 \\
P2 & 4,59 & 0,48 \\
P3 & 4,33 & 0,26 \\
\hline
\end{tabular}

Keterangan: Superskrip yang berbeda pada kolom yang sama menunjukan pengaruh yang nyata pada taraf 5\% $(P<0,05)$. 
Besarnya konversi pakan ayam P0, P1, P2, dan P3 tidak berbeda nyata yaitu berturutturut sebesar 4,33 g, 5,43 g, 4,59 g, dan 4,33 g. Hasil ini menunjukkan bahwa penambahan tepung kunyit pada dosis $0,12 \%$ tidak dapat meningkatkan konversi pakan pada ayam kampung super. Nilai konversi pakan yang sama antar perlakuan diduga karena besarnya PBBH yang sama meskipun konsumsi pakan berbeda nyata antar perlakuan. Hal ini sesuai dengan pendapat Sulaeman et al (2015) bahwa konversi pakan dipengaruhi oleh tingkat konsumsi pakan dan meningkatnya pertambahan bobot badan.

Konversi pakan dipengaruhi oleh tingkat konsumsi pakan, daya cerna dan gizi pakan yang seimbang. Hal ini sesuai dengan pendapat Krista (2010) bahwa semakin tinggi konversi pakan, artinya semakin rendah tingkat efisiensinya. Dengan demikian berdasarkan analisis statistik, peningkatan konversi pakan yang terjadi membuat pertumbuhan ayam semakin terhambat sehingga pertambahan bobot badan yang diperoleh tidak dapat mengalami peningkatan yang maksimal.

Rataan konversi pakan ayam kampung yang dipelihara lebih tinggi daripada standar konversi pakan ayam kampung pada umur 6,7,8 dan 9 minggu yaitu sebesar 2,81 g, 1,99 g, 2,04 g dan 2,16 g (Aryanti et al., 2013).

\section{KESIMPULAN}

Berdasarkan hasil penelitian yang telah dilakukan dapat disimpulkan bahwa penambahan tepung kunyit (Curcuma longa) sampai level $0,12 \%$ dalam pakan ayam kampung super berpengaruh terhadap konsumsi pakan namun tidak berpengaruh terhadap pertambahan bobot badan harian dan konversi pakan.

\section{DAFTAR PUSTAKA}

Adha, R.U., Widjastuti, T dan Abun, 2016. Pengaruh penambahan tepung kunyit dalam ransum terhadap performa ayam sentul putih pada priode grower. Fakultas Peternakan Universitas Padjajaran, Bandung.

Adi, R. 2009. Efektifitas Betain Pada Pakan Ayam Broiler Rendah Metionin Berdasarkan Parameter Berat Badan dan Karkas. Fakultas Pertanian. Universitas Sebelas Maret, Solo.

Aryanti, F., M. Aji dan N. Budiono. 2013. Pengaruh pemberian air gula merah terhadap performans ayam kampung pedaging. Sains Veteriner. 31. (2) : 126-421.

Furlan, R. L., Filho, D. E., Rosa, P. S. and Macari, M. 2004. Does lowprotein diet improve broiler perfomance under heat stress conditions, J of Poult, Brazillian. 6 (2) :71-79

Handayani, A., E. Yuniati dan B. Utomo. 2017. Penambahan Tepung Kunyit (Curcuma longa) Dalam Ransum Terhadap Performans Itik Hibrida Fase Grower. Skripsi. Universitas Nusantara PGRI, Kediri.

Hartati, S. Y. 2013. Khasiat Kunyit Sebagai Obat Tradisional dan Manfaat lainya. Warta Peneliti dan Pengembangan Tanaman Industri. 19 (2) : 5-9.

Jaelani, A. 2011. Performans Ayam Pedaging Diberi Enzim Beta Mannanase dalam Ransum yang Berbasis Bungkil Inti Sawit. Skripsi Peternakan. Jurusan Peternakan. Fakultas Peternakan. Universitas Islam Kalimantan. Kalimantan.

Krista, B.2010. Betrnak dan Bisnis Ayam Kampung. Agromedia Pustaka : Jakarta.

Olanrewaju, H. A., Thaxton, W. A., Dozier, I., Purswell, W. B. and Branton, S. I. 2006. A Review of lighting program for broiler production. Deprtemen of Poultry Science, Mississipi State University, Mississipi State, USA. 
Purwanti, S. Natsir, A. dan Syam, M. H. 2010. Kombinasi Kunyit, Bawang Putih dan Mineral Zink, Sebagai Feed Additive untuk Meningkatkan Performa Broiler. Seminar Nasional Teknologi Peternakan dan Veteriner, Makasar.

Sugiono. 2010. Metode Penelitian Pendekatan Kuantitatif, Kualitatif dan R\&D. Alfabeta, Bandung.

Sulaeman, Y., Ropik, S., Bachri, S., Sutriadi, M. T., \& Nursyamsi, D. 2015. Sistem informasi sumberdaya lahan pertanian Indonesia: status terkini dan arah pengembangan ke depan.

Widiawati, M.J., Muharlien dan Sjofjan, O. 2018. Efek Penggunaan Probiotik dan Tepung Kunyit (Curcuma Domestica Val) Pada pakan ayam Terhadap Performa Broiler. Jurnal Ternak Tropikal. $19: 105-110$.

Yusriani, Y. 2013. Kebutuhan Pakan untuk Ayam Kampung. Serambi Pertanian. Balai Pengkajian Teknologi Pertanian, Aceh. 